\title{
ANALISIS YURIDIS PERLINDUNGAN HUKUM TERHADAP ANAK DIBAWAH UMUR SEBAGAI PELAKU TINDAK PIDANA DITINJAU DARI UNDANG-UNDANG NOMOR 35 TAHUN 2014 TENTANG PERLINDUNGAN ANAK
}

\author{
Oleh: \\ Muhammad Suwandy Hasibuan ${ }^{1)}$, \\ Ismail $^{2)}$ \\ dan Irda Pratiwi ${ }^{3)}$ \\ Universitas Asahan 1,2,3) \\ E-mail: \\ mhdsuwandyhasibuan@gmail.com ${ }^{1)}$ \\ ismail_izu@yahoo.com ${ }^{2)}$ \\ danirdapratiwi@gmail.com ${ }^{3)}$
}

\begin{abstract}
Children are one of the vulnerable groups that need to be protected from all forms of human rights violations. We need to know that children's rights are a part of human rights that must be guaranteed by the state, protected by the state, and fulfilled by the parents who gave birth to them and this also applies to the community where the child is located. In this connection, the child has the right to growth and development and optimal survival both mentally, psychologically and also physically. The Criminal Code (KUHP) regulates violent crimes, in article 290 regarding crimes against decency, but according to the author the article has not caused a deterrent effect for perpetrators of acts of violence against children because the threat of punishment is still mild. So that with the Law Number 35 of 2014 amending the Law Number 23 of 2002 concerning Child Protection and Law Number 11 of 2012 concerning the Criminal Justice System. A normative juridical research method was used with a statutory approach. The formulation of the problem raised is how the legal protection of minors as perpetrators of crime is reviewed from Law Number 35 of 2014 concerning Protection of Children and how the regulation of restorative justice and diversion for legal protection of minors as perpetrators of crime. The writer can conclude that the government has tried to protect children who commit crimes under the child protection law through diversion.
\end{abstract}

Keywords: Legal Protection, Child Crimes, Diversity Efforts

\begin{abstract}
ABSTRAK
Anak merupakan salah satu golongan kelompok rentan yang perlu dilindungi dari segala bentuk pelanggaran Hak Asasi Manunisia. Kita perlu ketahui bahwa hak anak merupakana bagian yang diatur dalam hak asasi manusia yang wajib dijamin oleh negara, dilindungi oleh negara, dan dipenuhi oleh orang tua yang melahirkannnya dan ini juga berlaku bagi masyarakat dimana anak berada. Berkaitan dengan tersebut maka si anak berhak atas tumbuh kembang dan kelangsungan hidup secara optimal baik itu mental, psikiloginya dan juga fisiknya. Kitab undang-Undang Hukum Pidana (KUHP) telah mengatur tindak pidana kekerasan, dalam pasal 290 mengenai kejahatan terhadap kesopanan, namun menurut penulis pasal tersebut belum menimbulkan efek jera bagi pelaku tindakan kekerasan terhadap anak dikarenakan ancaman hukumannya masih ringan. Sehingga dengan adanya Undang-Undang Nomor 35 tahun 2014 perubahan atas Undang-undang Nomor 23 tahun 2002 tentang Perlindungan Anak dan UndangUndang Nomor 11 tahun 2012 tentang Sistem Peradilan Pidana. Dalam penulisan ini menggunakan metode penelitian yuridis normatif dengan pendekatan secara Perundangundangan. Rumusan masalah yang diangkat adalah Bagaimana perlindungan hukum terhadap anak dibawah umur sebagai pelaku tindak pidana ditinjau dari Undang-Undang Nomor 35 Tahun 2014 Tentang Perlindungan Anak dan Bagaimana pengaturan keadilan restoratif dan
\end{abstract}


diversi untuk perlindungan hukum terhadap anak dibawah umur sebagai pelaku tindak pidana.Maka dalam hal ini penulis dapat menyimpulkan bahwa pemerintah telah berupaya melakukan perlindungan terhadap anak yang melakukan tindak pidana berdasarkan undangundang perlindungan anak melalui diversi.

Kata Kunci : Perlindungan Hukum, Tindak Pidana Anak, Upaya Diversi

\section{PENDAHULUAN}

Keberadaan anak merupakan suatu kebahagiaan yang tertinggi dalam keluarga. Dari sudut pandangan hukum sendiri,seorang anak yang lahir dan tumbuh ditengah-tengah sebuah keluarga menimbulkan konsekuensi yuridis karena menimbulkan hak-hak dan kewajiban yang harus dipenuhi oleh keluarganya yaitu orang tuannya seperti memberikan pendidikan yang layak bagi anak. Kewajiban yang harus dipenuhi orangtua terhadap anak-anak dilandasi oleh falsafah moralitas bahwa anak itu merupakan amanat dari Tuhan yang harus dijaga dan dilindungi.Salah satu kewajiban orangtua terhadap anak adalah memberikan pendidikan yang terbaik sehingga anakanak tersebut menjadi generasi penerus bangsa dan memiliki peran strategis dalam menjamin eksistensi bangsa dan negara di masa yang akan datang. Agar kelak sang anak mampu memikul tanggung jawab tersebut. Pendidikan terbaik yang harus diperhatikan adalah pendidikan agama dan pendidikan moral.

Anak juga merupakan salah satu golongan kelompok rentan yang perlu dilindungi dari segala bentuk pelanggaran Hak Asasi Manusia. Dalam pasal 1 angka 12 undang-undang perlindungan anak menjelaskan bahwa dalam pasal tersebut memuat tentang hak-anak yang harus dilindungi, dijamin dan di penuhi baik itu keluarganya, masyarakat, pemerintah maupun negara. Berkaitan dengan tersebut maka si anak berhak atas tumbuh kembang dan kelangsungan hidup secara optimal baik itu mental, psikologi dan fisik dari anak tersebut. Di samping itu pula anak harus mendapatkan jaminan pemenuhan hak-haknya serta tanpa adanya perlakuan diskriminasi dan kekerasan. Namun pada kenyataannya masih terjadi pelanggaran terhadap hak anak, tercermin dari masih adanya anak-anak yang mengalami kekerasan.

Pada masa sekarang ini kekerasan dan penyalahgunaan seksual masa kanak hal yang sering terjadi yang sangat berdampak serius bagi tumbuh kembang anak. dampak yang terjadi apabila hal itu erjadi pada anak adalah ketakutan dan trauma yang berkepanjangan yang membuat anak tidak percaya siapapun. Bujuk rayu pelaku yang menurut anak baik itu menjadi polemik dalam pikiran anak yang menimbulkan perasaan bersalah pada diri si anak. Sebenarnya masalah seksual yang tidak mudah disampaikan oleh keluarga kepada anak menimbulkan ketidakpahaman yang terbawa terus kemasa dewasa yang akan mudah terjebak oleh pelaku seksual.

Pemberitahuan dan sosialisasi yang tidak mudah dipahami dan dimengerti oleh anak mengenai seksual menimbulkan keyakinan-keyakinan yang keliru dalam pola pikir anak.slah satu contohnya adalah self-blameyang merupakan perasaan rasa bersalah anak atas apa yang menimpanya dan merasa bahwa drinya itu aneh dan merasa bahwa kelahirannya di dunia sebagai pembawa kesialan bagi keluarganya

Salah satu kasus yang sering terjadi bagi anak adalahkasus pedofilia. Dimana kita ketahui bahwaPedofiliamerupakan seseorang yang merasa akan mendapatkan kepuasan seks apabila dilakukan dengan anak dibawah umur(Hanny Ronosulistyo, Aam Amirudin, 2004:33).Maka dari hal itu perlu adanya peraturan yang tegas untuk melindungi anak-anak dan menjerat pelaku pedofilia, sehingga pihak yang harus bertanggungjawab adalah ekspoitatornya atau si pelaku yang telah melakukan tindakan melanggar hukum (Ahmad Makki, 2016, https://ahmadmakki.wordpress.com, Di akses 27 Juli 2019, pukul 21.00 WIB) 
Salah satu contoh kasus yang pernah terjadi dan telah terungkap di Indonesia adalah kasus mantan Diplomat Australia yaitu William Stuart Brown, yang telah melakukan kejahatan seksual terhadap dua anak di Karangasem Bali. Dari kasus tersebut beberapa pihak merasa ada kemajuan bagi pihak penegak hukum dalam menagani kasus pedofilia yang terjadi di indonesia. Dimana pelaku di tindak secara tegas walaupun pada akhirnya Brown malakukan tindakan bunuh diri di Lembaga Permasyarakatan Amlapura, sehari setelah keputusan vonis itu dijatuhkan terhadapnya.Ada beberapa pelajaran penting yang bisa diambil dari kasus tersebut adalah tidak menutup kemungkinnan bahwa orang yang berpendidikan dan memiliki jabatan tinggi tidak melakukan perbuatan melawan hukum seperti pedofilia (Mufrisun Afandi, 2012).

Kitab undang-Undang Hukum Pidana (KUHP) telah mengatur tindak pidana kekerasan, dalam pasal 290 mengenai kejahatan terhadap kesopanan, namun menurut penulis pasal tersebut belum menimbulkan efek jera bagi pelaku tindakan kekerasan terhadap anak dikarenakan ancaman hukumannya masih ringan. Sehingga dengan adanya UndnagUndang Nomor 35 tahun 2014 perubahan atas Undang-undang Nomor 23 tahun 2002 tentang Perlindungan Anak dan UndangUndang Nomor 11 tahun 2012 tentang Sistem Peradilan Pidana Anak diharapkan dapat menimbulkan efak jera bagi pelaku dimana ancaman hukumannya lebih berat dibandingkan dengan KUHP dan pelaku dapat dikenakan denda.

\section{METODE PENELITIAN}

Dalam penulisan penelitian ini penulis menggunakan metode penelitian yuridis normatif dengan melakukan pendekatan masalah melalui Undangundang. Sumber bahan hukum yang digunakan dalam penulisan ini adalah dengan menggunakan data sekunder sebagai bahan utama yang terdiri dari bahan hukum primer yang antara lain bahannya adalah UUD 1945, KUHP,
Undang-Undang Nomor 35 tahun 2014 tentang perlindungan anak dan semua yang berhubungan dengan judul yang diangkat oleh penulis; bahan hukum sekunder yang merupakan bahan memberikan penjelasan terhadap bahan primer dan bahan hukum tersier sebagai bahan penunjang antara bahan hukum primer dan sekunder. Prosedur pengumpulan bahan hukum yaitu secara pustaka dan analisis bahan hukumnya secara kualitatif.

\section{HASIL dan PEMBAHASAN}

\subsection{Perlindungan Hukum Terhadap Anak Dibawah Umur Sebagai Pelaku Tindak Pidana Ditinjau Dari Undang-Undang Nomor 35 Tahun $2014 \quad$ Tentang Perlindungan Anak serta Pengaturan Keadilan Restoratif}

Perlindungan hukum terhadap Anak menurut Undang-Undang Nomor 35 Tahun 2014 tentang Perlindungan Anak adalah segala bentuk kegiatan yang dilakukan untuk melindungi dan menjamin kehidupananak dan hak-hak dari anak agar dapat bertumbuh kembang dan hidu secara optimal sesuai dengan harkat dan martabat kemanusiaan juga serta mendapatkan perlindungan dari segala bentuk kejahatan dan kekerasan serta diskriminasi, ini berdasarkanberdasarkan dari yang dituangkan dalam pasal 1 ayat (2).Perlindungan hukum yang tertuang dalam pasal tersebut diatas menurut Barda Nawawi Arief adalah bahwa suatu upaya perlindungan hukum terhadapberbagai kepentingan yang berhubungan dengan kesejahteraan anak, kebebasan dan serta hak asasi anak yang perlu dilindungi dan dipenuhi (fundamental right and freedoms of children) (Muladi dan Barda Nawawi Arief, 2005:153).

Perlindungan khususterhadap anakyang diberikan oleh negara yang dituangkan dalam undang-undang atau peraturan yang berkaitan dengan hal tersebut berhadapan dengan hukum dalam ranah hukum pidana diberikan kepada anak yang menjadi korban tindak pidana, saksi dan pelaku tindak pidana yang artinya bahwa ketiga unsur tersebut mendapatkan 
perlindunngan khusus. Mengenai perlindungan khusus terhadap anak korban tindak kekerasan telah diatur dalam Pasalnya yang ke 69 Undang-Undang Nomor 35 Tahun 2014 tentang Perlindungan Anak yang menyatakan bahwa perlindungan khusus yang diberikan bagi anak korban kekerasan yang artinya bahwa korban kekerasa yaitu anak memiliki perlindungan khusus dalam undangundang.

Pasal 2Undang-Undang Dasar 1945 menjelaskan bahwa penyelanggaraan perlindungan anak harus berlandaskan terhadap prinsip-prinsip dasar Konvensi Hak-Hak Anak yang meliputi kepentingan yang terbaik bagi anak,penghargaan terhadap anak, non diskriminasi, hak untuk hidup, kelangsungan hidup dan perkemban. Nilai-nilai yang terkandung serta prinsipprinsip tersebut harus menjadi landasan dalam pengambilan keputusan dalam perlindungan anak, baik oleh badan eksekutif, legislatif, maupun yudikatif dalam penerapannya.

Dalamproses peradilan pidana anak perlu adanya pengembangan hak-hak anak guna mewujudkan perlindungan hukum bagi anak sertaperlu mengerti permasalahan yang sedang terjadi menurut proporsi yang sebenarnya secara meluas, dimensional dan terpadu agart tidak merugikan anak dan menghentikan tumbuh kembang anak. Sebab pengembangan hak-hak anak dalam proses peradilan pidana akan membantu dalam permasalahan yang terjadi terhadap anak yang mendapatkan jalan tengah terhadap kasus tersebut (Wagiati Soetodjo, 2006:69).

Indonesia merupakan salah satu dari banyak Negara yang meratifikasi Konvensi Hak Anak, maka dari itu dibentuk Undang-Undang Perlindungan Anak sebagai perwujudan perlindungan terhadap anak di Indonesia. Perlindungan yang diharapkan tidak hanya berlaku kepada anak yang menjadi korban kejahatan ataupun pemenuhan hak-hak anak dalam memperoleh pendidikan, namun juga memberikan perlindungan serta payung hukum bagi anak yang berkonflik dengan hukum dan tindak pidana.
Sebagaimana dimaksud dalam Pasal 59 meliputi kekerasan fisik, psikis, dan seksual dilakukan melalui upaya penyebarluasan dan sosialisasi ketentuan peraturan perundang-undangan yang melindungi anak korban tindak kekerasan; dan Pemantauan, pelaporan, dan pemberian sanksi. Pemerintah sebagaimana amanat Undang-Undang Nomor 23 Tahun 2002 tentang Perlindungan Anak telah membentuk Komisi Perlindungan Anak Indonesia (KPAI) guna memberikan perlindungan terhadap anak Indonesia.

Undang-Undang Nomor 11 Tahun

2012 Tentang Sistem Peradilan Pidana Anak (SPPA) yang diundangkan pada tanggal 30 Juli 2012 (TLNRI 2012-153) merupakan pengganti Undang-Undang Nomor 3 Tahun 1997 tentang Pengadilan Anak yang efektif mulai berlaku setelah 2 (dua) tahun terhitung sejak tanggal diundangkan.

Apabila ditelusuri, alasan utama pengganti Undang-Undang tersebut dikarenakan Undang-Undang Nomor 3 Tahun 1997 sudah tidak sesuai lagi dengan perkembangan dan kebutuhan hukum masyarakat karena secara komprehensif belum memberikan perlindungan kepada anak yang berhadapan dengan hukum (Wagiati Soetodjo, 69).Terkait dengan umur anak, anak yang belum berumur 12 (dua belas) tahun, walaupun melakukan tindak pidana, belum dapat diajukan ke sidang Pengadilan Anak. Hal demikian didasarkan pada pertimbangan sosiologis, psikologis dan paedagogis, bahwa anak yang belum berumur 12 (dua belas) tahun itu belum dapat mempertanggungjawabkan perbuatannya.

Anak yang belum berumur 12 (dua belas) tahun dan melakukan tindak pidana tidak dapat dikenai sanksi pidana maupun sanksi tindakan. Untuk menentukan apakah kepada anak akan dijatuhkan pidana atau tindakan, maka hakim mempertimbangkan berat ringannya tindak pidana yang dilakukan. Di samping itu juga diperhatikan, keadaan anak, keadaan rumah tangga orang tua/wali/ orang tua asuh, hubungan antara anggota keluarga, dan keadaan lingkungannya.Di samping itu hakim juga wajib memperhatikan laporan 
pembimbing kemasyarakatan. Menurut Undang-Undang Nomor 11 tahun 2012 tentang Sistem Peradilan Pidana Anak, Pasal 69 ayat 2, anak yangbelum berusia 14 (empat belas) tahun hanya dapat dikenai tindakan.

Pasal 70 menyatakan bahwa ringannya perbuatan, keadaan pribadi anak, atau keadaan pada waktu dilakukan perbuatan atau yang terjadi kemudian dapat dijadikan dasar pertimbangan hakim untuk tidak menjatuhkan pidana atau mengenai tindakan dengan mempertimbangkan segi keadilan dan kemanusiaan. Dengan demikian undang-undang baru mengubah usia pertanggungjawaban pidana, dari minimal delapan tahun menjadi 12 sampai 18 tahun. Batasan usia yang bisa ditahan 14 sampai 18 tahun.Didalam Pasal 95 UndangUndang Sistem Peradilan Pidana Anak yang memberikan ancaman sanksi administratif dan pasal 96 yang memberikan ancaman pidana penjara paling lama 2 (dua) tahun atau denda paling banyak Rp 200.000.000,00 (dua ratus juta rupiah).

Untuk menentukan apakah suatu perbuatan dilakukan dengan sengaja yang menimbulkan suatu akibat yang dilarang harus dipelajari ajaran kausalitet. Dimana ajaran ini bertujuan untuk menentukan hubungan sebab dan akibat artinya bilamana akibat tersebut dapat ditentukan oleh suatu sebab. Tanpa mempelajari kausalitet orang tidak akan tahu siapa yang melakukan tindak pidana tersebut (Suharto. R.M, 2002:58).Menurut Andi Hamzah, berkaitan dengan hal-hal tersebut, dapat diketahui bahwa terjadinya delik hanya pada delik yang mensyaratkan akibat tertentu, yaitu delik materiel, misalnya pembunuhan (pasal 338, pasal 340 KUHP), peni-puan (pasal 378 KUHP) daan delik culpa, misalnya karena kelalaiannya mengakibatkan kematian orang lain (pasal 359 KUHP), karena lalainya, menyebabkan lukanya orang lain (pasal 360 KUHP), dan sebagainya (Andi Hamzah, 1991:144).

Pasal 338 KUHP menyebutkan bahwa barang siapa sengaja merampas nyawa orang lain, diancam karena pembunuhan, dengan pidana penjara paling lama lima belas tahun. Bagian inti delik ini adalah "dengan sengaja" serta "merampasnyawa orang lain." Kesengajaan disini ditujukan kepada hilangnya nyawa orang lain, inilah yang membedakan dengan penganiayaan, tidak ada maksud atau kesengajaan untuk menghilangkan nyawa orang. Matinya orang itu hanya akibat dari penganiayaan.

Bentuk pelaksanaan dalam membina anak pelaku tindak pidana di aturdalam Pasalya yang ke 20 UndangUndang Nomor 12 Tahun 1995 tentang Pemasyarakatan di lembaga permasyarakatan. Penggolongan dalam membina anak pelaku tindak pidana berdasarkan dari jenis kelamin,umur, jenis kejahatan, lamanya pidana yang dijatuhkan dan kriteria lainnya sesuai dengan kebutuhan atau perkembangan pembinaan terhadap anak pelaku tindak pidana.

\subsection{Diversi untuk perlindungan hukum terhadap anak dibawah umur sebagai pelaku tindak pidana}

Pengaturan keadilan restoratif dan diversi diharapkan dapat berlaku di semuatingkatan pemeriksaan dan diharapkan anak yang telah melakukan tindak pidanasebisa mungkin tidak masuk ke dalam proses peradilan. Dalam penjelasan umum Undang-Undang Sistem Peradilan Pidana Anak menyebutkan bahwa Adapun substansi yang diatur dalam Undang-Undang ini yaitu antara lain, pengaturan secara tegas mengenai Keadilan Restoratif dan mengenai adanya penempatan Anak yang menjalani proses peradilan dapat ditempatkan di Lembaga Pembinaan Khusus Anak (LPKA). Diversi yang dimaksudkan untuk menghindari dan menjauhkan Anak dari proses peradilan sehingga dapat menghindari stigmatisasi terhadap Anak yang berhadapan dengan hukum dan diharapkan Anak dapat kembali ke dalam lingkungan sosial secara wajar. (Penjelasan Umum Undang-Undang Sistem Peradilan Pidana Anak).

Restoratif Justiceatau keadilan secara restoratif dianggap mampu sebagai model penghukuman modern pada masa sekarang ini dan lebih manusiawi dalam putusan hukumannya terhadap anak-anak 
berhadapan dengan hukum. Prinsip dari keadilan restoratif adalah hasil perbandingan daneksplorasiantara pendekatan keadilandengan pendekatan kesejahteraan yang menghasilkan putusan yang terbaik bagi pelaku dan korban. Konsep dasar yang melatarbelakangi adanya model restoratif adalah teori dari salah satu pakar hukum John Braintwaite yang dikenal sebagaiReintegrative scheme.

Keadilan restoratif dilandasi dari pada prinsip-prinsip due process yang sangat menghormati dan menghargai dari hak-hak hukum tersangka atau pelaku, seperti hak untuk diperlakukan sebagai orang yang tidak bersalah hingga pengadilan menvonis bahwa dia ditetapkan sebagai pelaku tindak pidana, hak untuk membela diri dan mendapatkan hukuman yang sesuai dengan kejahatan yang dilakukannya tersebut (M. Ghufran $\mathrm{H}$. Kordi K, 2010:242).

Diversi (diversion) adalah pengalihan penanganan kasus-kasus anak yang diduga telah melakukan tindak pidana dari proses formal dengan atau tanpa syarat. Tujuan diversi adalah : menghindari cap/stigma sebagai penjahat, mencegah memajukan suatu intervensi-intervensi yang diperlukan bagikorban,anak tidak perlu ditahan, ,peluang bagi pelaku bertanggungjawab atas perbuatannya,peluang bagi pelaku meningkatkan ketrampilan hidup, tidakmelakukan pengulangan tindak pidana, ,menghindarkan anak mengikuti proses sistem peradilan, menjauhkan anak-anak dari pengaruh dan implikasi negatif dari proses peradilandan pelaku tanpa harus melalui proses formal (M. Ghufran $\mathrm{H}$. Kordi K, 2010:248).

Ketentuan tentang Keadilan Restoratif di tegaskan di dalam pasal 5 dan ketentuan tentang Diversi diatur dalam pasal 6 sampai dengan pasal 15 UndangUndang Sistem Peradilan Pidana Anak.

Dalam Pasal 5 disebutkan :

(1) Sistem Peradilan Pidana Anak wajib mengutamakan pendekatan Keadilan Restoratif.
(2) Sistem Peradilan Pidana Anak sebagaimana dimaksud pada ayat (1) meliputi sebagai berikut :

a. Penyidikan dan penuntutan pidana Anak yang dilaksanakan sesuai dengan ketentuan peraturan perundang-undangan, kecuali di tentukan lain dalam Undang-Undang ini;

b. Persidangan Anak yang dilakukan oleh pengadilan di lingkungan pengadilan umum; dan

c. Pembinaan, pembimbingan, pengawasan, dan/ atau pendampingan selama proses pelaksanaan pidana atau tindakan dan setelah menjalani pidana atau tindakan.

(3) Dalam Sistem Peradilan Pidana Anak sebagaimana dimaksud pada ayat (2) huruf a dan huruf b wajib diupayakan Diversi.

Pengaturan tentang Diversi ditegaskan dalam pasal 6 sampai dengan pasal 15, dimana dalam pasal-pasal tersebut menjelaskan mengenai tujuan dari diadakannya diversi, upaya pemberlakuan diversi, kategori diversi, proses diversi, pelaksanaan diversi sampai dengan hasil dari diversi. Ini dilakukan supaya ada bentuk upaya hukum yang dapatmenyelesaikan perkara pidana anak tanpa harus berhadapan dengan proses pengadilan. Penerapan Keadilan Restoratif dan Diversi dalam pelaksanaan sistem pidana anak di Indonesia membantu mewujudkan perlindungan anak yang berdasar pada ke-5 sila yang terdapat di dalam Pancasila serta berdasar pada UUD 1945. Dikatakan demikian sebab anak tidak dipisahkan dari lingkungan keluarga dan masyarakat serta tidak mengesampingkan hak dan pendidikan anak dalam praktiknya, sehingga diperlukan penerapannya dalam penanganan anak. 


\section{KESIMPULAN dan SARAN}

\section{Kesimpulan}

1. Perlindungan Hukum yang diberikan kepada anak dibawah umur sebagai pelaku tindak pidana ditinjau dari Undang-Undang Nomor 35 Tahun 2014 merupakan perubahan atas Undang-Undang Nomor 23 Tahun 2002 yang mengatur tentang Perlindungan Anak.

2. Ketentuan tentang Keadilan Restoratif di tegaskan di dalam pasal 5 dan ketentuan tentang Diversi diatur dalam pasal 6 sampai dengan pasal 15 Undang-Undang Sistem Peradilan Pidana Anak.

\section{Saran}

1. Diharapkan kepada Pemerintah Pusat maupun Pemerintah Daerah agar dapat memberikan perlindungan semaksimal mungkin dan memberikan sanksi yang tegas agar tercipta keharmonisan di dalam kehidupan masyarakat sehari-hari.

2. Diharapkan kepada para aparatur penegak hukum baik dari kepolisian, jaksa, dan hakim agar dapat menerapkan keadilan secara restoratif serta melakukan penyuluhan agar dapat mencegah terjadinya hal-hal yang tidak diinginkan

\section{DAFTAR PUSTAKA}

\section{A. Buku}

Hanny Ronosulistyo, Aam Amirudin, 2004, Seks tak Sekedar Birahi, Panduan Lengkap Seputar Kesehatan Reproduksi: Tinjaauan islam dan Medis, Bandung: Gernada.

Mufrisun Afandi, 2012, ArtikelPedophilia, Belajar dari Kasus Mantan Diplomat, Jakarta.

Muladi dan Barda Nawawi Arief. 2005,Teori-Teori dan Kebijakan Pidana, cetakan ketiga, P.T. Alumni Bandung.

Wagiati Soetodjo, 2006, Hukum Pidana Anak, Refika Aditama, Bandung.

Suharto. R.M., 2002, Hukum Pidana Materiil, Jakarta: Sinar Grafika.

Andi Hamzah, 1991, Asas-Asas Hukum Pidana, Jakarta: Rineka Cipta.

M. Ghufran H. Kordi K., 2010Hak dan Perlindungan Anak di atas kertas, P.T Perca, Jakarta.

\section{B. Undang-undang}

Undang-Undang Nomor 35 Tahun 2014 Tentang Perlindungan Anak.

Undang-Undang No.11 tahun 2012 tentang Sistem Peradilan Pidana Anak

Penjelasan Umum Undang-Undang Sistem Peradilan Pidana Anak

\section{C. internet}

Ahmad Makki, 2016, https://ahmadmakki.wordpress.c om, Di akses 27 Juli 2019, pukul $21.00 \mathrm{WIB}$ 